ENTREPRENEURSHIP AND SUSTAINABILITY ISSUES

ISSN 2345-0282 (online) http://jssidoi.org/jesi/

2020 Volume 7 Number 4 (June)

http://doi.org/10.9770/jesi.2020.7.4(47)
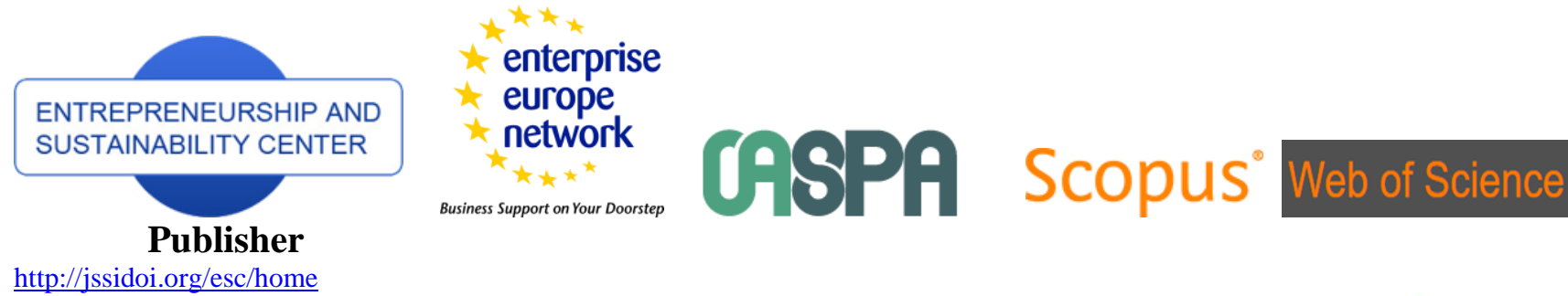

http://jssidoi.org/esc/home

Business Support on Your Doorstep

1 Clarivate

Analytics

\title{
PROBLEM LOAN MANAGEMENT IN THE COUNTRIES OF THE EURASIAN ECONOMIC UNION
}

\author{
Kalamkas Rakhimzhanova ${ }^{1}$, Serik Makysh ${ }^{2}$, Botagoz Saparova ${ }^{3}$, Baurzhan Iskakov ${ }^{4}$ \\ ${ }^{1,2,3}$ L.N. Gumilyov Eurasian National University, Nur-Sultan, Kazakhstan \\ ${ }^{4}$ Turan- Astana University, Astana, Kazakhstan \\ E-mails:른alamkas.Rakhimzhanova@mail.ru; ${ }^{2}$ Makysh.sb@yandex.kz; ${ }^{3}$ finmensaparova@yandex.kz; ${ }^{4}$ Iskakov82@mail.ru
}

Received 16 December 2019; accepted 11 April 2020; published 30 June 2020

\begin{abstract}
The article discusses issues of managing problem loans in the countries of the Eurasian Economic Union. The main goal of the article is to solve problems for realizing the positive effects of easing the conditions of bank lending, identifying barriers and constraints taking into account the current policy to free the banking sector from unscrupulous participants. Therefore, the relevance of the topic determines that the problems raised by the authors in the article require a comprehensive study and comprehensive analysis preparing a scientific justification.Based on the identified goal, the authors analyzed approaches to determining problem assets in the banking system, the dynamics of indicators for the development of the banking sector, the share of problem loans in the banking system of the countries of the Eurasian Economic Union, a consolidated report on the profit and loss of commercial banks, the problems of unsuccessful and problem loans - NPL. Based on the study, conclusions are drawn and recommendations are given. The solution to these problems involves the prevention of banking risks, assessing the adequacy of the formation of provisions for possible losses on loans and the compliance of the business models used by credit organizations with their capabilities.
\end{abstract}

Keywords: entrepreneurship; entrepreneurial activity; factors; business environment

Reference to this paper should be made as follows: Rakhimzhanova, K., Makysh, S., Saparova, B. 2020. Problem loan management in the countries of the Eurasian Economic Union. Entrepreneurship and Sustainability Issues, 7(4), 3286-3308. http://doi.org/10.9770/jesi.2020.7.4(47)

JEL Classifications: Z3, L15.

\section{Introduction}

In the process of carrying out their activities, commercial banks are exposed to a whole range of banking risks. All types, groups and subgroups of banking risks are interconnected and interdependent. Most banking risks contain elements of other risks. However, of all banking risks, credit risk is the most significant, since most of the financial losses and bankruptcies of banks are due to non-return by borrowers of loans and the bank's illconceived risk policy (Fakhry et al., 2018; Tvaronavičienè et al., 2018; Ashraf et al., 2019; Rahman et al., 2019; Caplinska, Tvaronavičienè, 2020, Siddique et al., 2020). 


\section{ENTREPRENEURSHIP AND SUSTAINABILITY ISSUES}

ISSN 2345-0282 (online) http://jssidoi.org/jesi/

2020 Volume 7 Number 4 (June)

http://doi.org/10.9770/jesi.2020.7.4(47)

Thus, at present, the most effective and common methods for managing problem debt are the independent work of the bank to return the problem debt or selling loan portfolios to collection agencies. Most banks use several methods: in the early stages they work independently with problem debts, and in the later stages they transfer it to collection companies or sell them to third parties. However, it should be noted that subject to the availability of small amounts of debt on loans (when the costs of finding a borrower exceed the amount of the debt itself) they are written off at the expense of the bank's reserves.

\section{Literature review}

According to the article, the author suggests that in modern economic literature there is no single approach to the definition of problem loans of a commercial bank. Formulating a definition in a broad sense, we can give the following characteristic - obligations of legal entities, for which signs of impairment were identified and / or factors that could affect the timeliness and fullness of repayment were identified. In the narrow sense, debt on credit products, part of which is on the accounts of accounting for overdue loans (Bizin, 2016).

Therefore, the emergence of problem loans as a result of the realization of credit risk occurs regardless of external economic conditions. Crisis phenomena only affect the likelihood of problem loans and lead to their growth (Baibulekova, 2016).

Some authors suppose that the portfolio of problem loans is one of the components of the loan portfolio of the bank and represents the totality of all problem loans of a banking organization (Platonova, Zaichenko, 2018).

Others consider such a credit debt problematic, according to which the bank sees the danger of timely and full repayment as a result of various factors (economic, legal, social, etc.) (Yusupova, 2015).

Based on the study of foreign experience, K.R. Tagirbekova claims that in the presence of a large number of banks experiencing difficulties, as well as a certain degree of uniformity of acquired assets, a centralized method of restructuring the banking system is the most effective. The purchase or transfer of non-performing assets to the disposal of state-owned sanitation organizations has established itself as a very effective tool (Tagirbekova, 2015).

Foreign experience of bad banks, as described in his scientific articles by D. Potapeyko, is successful. In the 1990s, banks with distressed assets in Sweden managed to recover a third of the book value of bad debts. At the moment, at the end of March, the US Treasury Department announced the long-awaited program, called "TARP" (Troubled Asset Relief Program). Its essence lies in the redemption of "toxic assets" from banks and their transfer to the balances of specially created private-state investment funds (Potapeyko, 2014).

According to researcher, the management of problem loans should be considered as a process that is characterized by all the features of management: strategic, tactical, and organizational. Therefore, he considers:

- "pre-problem debt" is debt in the framework of which the client has violated the terms of the loan agreement, including the terms on the maturity of the main obligation and / or interest, the conditions of preservation and amount of collateral, the conditions for maintaining the financial situation, etc.

- "bad debt" - debt, which is assigned the status of bad debt, i.e. there are significant, more than 60 days, violations of the deadlines for fulfillment of obligations to the bank, a significant deterioration in the financial condition of the debtor, a significant deterioration in the quality or loss of security;

- "doubtful debt" is debt in respect of which the bank has doubts about timely repayment of the principal obligation and / or interest.

- "overdue debt" is a debt for which there has been a violation of the repayment terms of the main obligation and / or interest (Aleksandrov 2017). 


\section{ENTREPRENEURSHIP AND SUSTAINABILITY ISSUES}

ISSN 2345-0282 (online) http://jssidoi.org/jesi/

2020 Volume 7 Number 4 (June)

http://doi.org/10.9770/jesi.2020.7.4(47)

According to the authors, in various economic conditions, the tasks that a bank faces in selling a claim to a loan portfolio differ. In stable economic conditions, the sale of a portfolio is used as a tool to raise additional funds, and crisis conditions lead to the cession being perceived as an opportunity to clean the balance from non-core or distressed assets (Aliev, Ibragimova, Dzhamalova, 2016).

Studies in the field of troubled loan management, it is said that this is becoming one of the key aspects of a commercial bank, the tasks of which are faced by the bank's system of managing troubled assets are:

- identification of possible sources of troubled debt in the framework of existing obligations, as well as those planned for issuance in the short term;

- identification and regulation of industry concentration of the probability of default for corporate borrowers;

- assessment of the impact of the portfolio of problem loans on the financial results of the Bank in the reporting period;

- determination of sources of credit risk coverage in the event of a possible default of the counterparty;

- development, implementation and evaluation of the effectiveness of methods of neutralizing or resolving bad debts;

- monitoring of repayment of the current portfolio of problem loans (Rubleva, 2017).

\section{Materials and methods}

The quality of banking assets and, above all, loans is one of the most important indicators of the state of the banking sector and the country's economy as a whole. One of the main indicators used to assess the quality of banks' loan portfolios and their assets is the share of bad debt, which contributes to a deeper understanding of the existing dependencies in the economy and the identification of the main vulnerabilities of the financial system.

In banking science and practice, there is no single clearly defined indicator that gives a quantitative idea of bad debt. For example, the International Monetary Fund regards bad debt as a liability, the full repayment of which is doubtful due to the inadequate financial condition of the debtor or collateral for this obligation, and there is an delay in payment of the principal and / or interest on it for more than 90 days.

Based on the approaches, the US Federal Banking System is a loan that does not generate income, that is, interest payments delayed by more than 90 days.

In accordance with the income of the Basel Committee on Banking Supervision, bad debt is a loan product for which there are significant violations of the deadlines for fulfillment of obligations to the bank, a significant deterioration in the quality of collateral or its loss.

In conditions of macroeconomic instability and crisis phenomena, banks should pay increased attention to risk assessment and management. Credit risk is one of the main risks in the banking sector. As one of the main levels of credit risk, many experts and professionals consider the NPL indicator (doubtful and bad loans). This indicator reflects the quality of the loan portfolio in the banking sector.

Today, in the financial system, issues of primary importance have come to the fore, with which the problem of stability of the entire financial and economic system is associated. Among these issues is the problem of NPL, or problem loans.

If we consider the data of the World Bank regarding the share of NPL by region, country and year (starting from the crisis of 2008 to 2017 inclusive), then it is clear that the first blows of the global financial and economic crisis were taken by developed countries - such as Germany, France, the Czech Republic, Austria, Poland, the United 


\section{ENTREPRENEURSHIP AND SUSTAINABILITY ISSUES}

ISSN 2345-0282 (online) http://jssidoi.org/jesi/

2020 Volume 7 Number 4 (June)

http://doi.org/10.9770/jesi.2020.7.4(47)

States and others, where during the crisis years the share of problem loans increased sharply. However, in subsequent years, it gradually began to decline. This indicates that these countries are emerging from the crisis, overcoming the problems arising from it and reducing the possibility and threat of a new crisis.

And the situation is quite different in the case of many developing countries whose economies have not been directly affected by the global crisis, and where the share of NPL has remained at an acceptable low level for some time. However, in the post-crisis years in countries such as Kazakhstan, Ukraine, Belarus, Russia and others, including Armenia, the share of bad loans began to increase, in this regard, new anti-records were set, and the consequences of the crisis began to deepen, that is, these countries hit into the maelstrom of the crisis with some lag in time.

Here, of course, it should be emphasized that the increase in NPL is due not only to the activities of the financial and banking system, but also to the state of the entire economy.

In the case of Armenia, if we consider certain areas of the economy, it should be noted that the share of nonperforming loans in the portfolio of consumer loans reached 20 percent or more, in mortgage lending - $6 \%$, in construction $-6 \%$, in agriculture $-19 \%$, in industry $-15 \%$, in the commercial sector $-16 \%$, which indicates a decrease in household incomes, and this, in turn, is accompanied by inflation. In the case of business, a decrease in turnover is observed.

In total, in Armenia, the share of NPL in the loan portfolio from 2008 to 2012 was in a narrow range from $4.10 \%$ to $4.86 \%$. However, after 2013 , the share of non-performing loans began to increase sharply, reaching from $5.56 \%$ in 2013 to $8.53 \%$ in 2014 and peak $9.48 \%$ in 2015 . Over the past two years, this figure has been insignificantly reduced by a tenth of a percent, amounting to $9.41 \%$ in 2016 and $9.02 \%$ last year. Thus, at present, in comparison with the pre-crisis indicators, we now have a double increase in the share of NPL in the total loan portfolio.

Not limited to these official figures, it should be noted that in the real picture the tones are even darker, and the sizes presented by the NPL should be slightly larger. The fact is that today banks are actively refinancing loans to borrowers in a difficult situation, as a result of which such loans are not included in the problem, remaining standard, but in reality they are problem. In Armenia, the volume of loans officially recognized as past due is more than three times lower than extended.

This camouflages the problems and risks that have matured before the banking system. From the above it can be concluded that in the absence of a real and carefully verified picture, we may face serious risks threatening the financial and economic system, when even a relatively small systemic shock will lead to a sharp increase in the share of NPL.

And even in the absence of shocks, we can become eyewitnesses of how the next financial crisis, possibly of a regional scale, raises its head again. This can happen if accelerated development is not achieved in the economies of our countries, and the degree of inflation continues to increase, the solvency of the population decreases, and the activity of the business decreases, which implies a slowdown in the annual growth of the economy. Including the above problems, a more stringent version of the principles of Basel-3 appeared which sufficiently creates new requirements for capital - an additional amount of up to $7 \%$.

\section{Results and Discussion}

Of course, the capitalization of banks is partially able to solve the problem, but not completely, since covering all risk with capital will increase the value of money. The most important and effective solution lies in the plane of 
ongoing work with banks in banks so that more accurate analyzes are carried out and the existing problems and risks are not hidden. Of course, governments and central / national banks should also deal with these problems, start a dialogue with structures representing the financial sector in order to solve problems - from sphere to sphere, from problem to problem, from region to region. The net profit of the banking system of Armenia for the first quarter of this year amounted to 20.1 billion drams ( $\$ 41.7$ million) against 10.7 billion (\$22.2 million) for the same period last year, an increase of $87,2 \%$. According to reports, all 17 banks operating in the country completed the 1 st quarter with a profit. At the same time, during the reporting period, Armenian banks increased credit investments by more than $1.7 \%$ - up to almost 2.7 trillion. drams ( $\$ 5601.7$ million). The main problem, of course, however, proceeds from the general state of the economy, however, we, being active representatives of the financial system, give manageability to the problems facing the banking system, ensuring stability and stability of the financial and economic system of this country and region (table 1).

Table 1. Dynamics of development indicators of the banking sector of Armenia

\begin{tabular}{|c|c|c|c|}
\hline № & Name of indicator & $\begin{array}{l}\text { unit of } \\
\text { measurement }\end{array}$ & 2017 \\
\hline 1 & Number of existing credit organizations (KO) & unit & 17 \\
\hline 2 & The number of corporate bonds with foreign participation & unit & 17 \\
\hline 2.1 & - including with $100 \%$ share of foreign capital & unit & 9 \\
\hline 3. & The number of branches of operating KO & unit & 529 \\
\hline 4. & Own funds (capital) $\mathrm{KO}$ & thousand dollars & 1488394,2 \\
\hline 5. & $\mathrm{CO}$ assets - total & thousand dollars & 9012569,0 \\
\hline 5.1 & - loan debt -total & thousand dollars & 5894036,6 \\
\hline 5.1 .1 & - including past due & thousand dollars & 437737,6 \\
\hline 5.2 & - loans granted to individuals & thousand dollars & 1701901,7 \\
\hline 5.3 & - loans to non-financial organizations & thousand dollars & 3940786,8 \\
\hline 6 & Liabilities KO-total & thousand dollars & 9012569,0 \\
\hline 6.1 & Deposits of individuals & thousand dollars & 3221056,2 \\
\hline 6.2 & $\begin{array}{l}\text { Resources attracted by credit organizations in the interbank } \\
\text { market }\end{array}$ & thousand dollars & 111816,3 \\
\hline 7 & Financial result of the banking sector & thousand dollars & 79132,2 \\
\hline 8 & $\begin{array}{l}\text { Minimum amount of capital for existing credit } \\
\text { organizations }\end{array}$ & thousand dollars & 61983,471 \\
\hline \multirow[t]{2}{*}{9} & Refinancing rate (key rate) of the National Bank & $\%$ & 6 \\
\hline & For reference: & & \\
\hline 10 & Gross domestic product & thousand dollars & 11529167,1 \\
\hline
\end{tabular}

Source: compiled and calculated by authors 


\section{ENTREPRENEURSHIP AND SUSTAINABILITY ISSUES}

ISSN 2345-0282 (online) http://jssidoi.org/jesi/

2020 Volume 7 Number 4 (June)

http://doi.org/10.9770/jesi.2020.7.4(47)

So, for example, in 2015, the share of non-performing loans in the portfolio of loans of Armenia provided by commercial banks amounted to $7.2 \%$ or about 172 billion drams, the largest part of which was provided to individuals, in particular consumer loans - $1.64 \%$ or Mortgage loans accounted for 39.2 billion drams and $0.51 \%$ or 12.2 billion drams.

In 2016, non-performing loans accounted for $6.9 \%$ of all loans or 167.5 billion drams, the largest part of which was provided to individuals, in particular consumer loans - $8 \%$ or 43.7 billion drams, and mortgage loans $-0.66 \%$ or about 16 billion drams.

In 2017, non-working loans accounted for about $6.3 \%$ of all loans issued or 174.6 billion drams, of which the highest percentage was non-working loans to individuals, in particular, consumer loans $-1.4 \%$ or 38.8 billion AMD, mortgage loans $-0.51 \%$ or AMD 14.1 billion.

At the end of the first quarter of 2018, non-performing loans amounted to $5 \%$ or 150.9 billion drams of all loans issued to residents by commercial banks. Non-performing loans to individuals, in particular consumer loans amounted to $1.1 \%$ or 33.2 billion drams, and mortgage loans $-0.3 \%$ or 9.1 billion drams.

Analyzing the dynamics of the share of loans to individuals in non-performing loans in the loan portfolio of commercial banks, for the period 2015-2018 we see the following picture (table 2).

Table 2. Indicators characterizing non-performing loans in the portfolio of commercial banks of Armenia

\begin{tabular}{|c|l|c|c|c|c|}
\hline № & \multicolumn{1}{|c|}{ Indicator } & 2015 & 2016 & 2017 & $\begin{array}{c}\text { First quarter of } \\
2018\end{array}$ \\
\hline 1 & $\begin{array}{l}\text { The share of loans to individuals in non-performing } \\
\text { loans in the loan portfolio of commercial banks }\end{array}$ & 51,4 & 59,7 & 52,9 & 42,3 \\
\hline 2 & $\begin{array}{l}\text { Absolute volumes of non-performing loans to } \\
\text { individuals }\end{array}$ & 2,15 & 2,46 & 1,91 & 1,4 \\
\hline
\end{tabular}

Source: compiled and calculated by authors

As can be seen from table 2, non-performing loans to individuals have the largest share in 2016, and then it decreased significantly in the first quarter of 2018 and reached $1.4 \%$.

As for the dynamics of the absolute volumes of non-working loans to individuals for the same period, the dynamics of the volume of non-working loans to individuals has the same trajectory as was observed in the case of their specific weight. Non-working loans to individuals in 2016 amounted to 59.7 billion drams, and then fell sharply in the first quarter of 2018 and reached 42.3 billion drams.

Thus, as a result of the legislative amendment, commercial banks will have the opportunity, without additional tax obligations, to forgive individuals the fines and penalties charged on loans recognized as uncollectible for more than 42.3 billion drams accumulated until May 31, 2018. The latter will be an important step both for the financial situation of Armenian citizens, and for improving the loan portfolio of commercial banks, since in this case the amounts payable for overdue loans of individuals will be used to repay the main The total amount and interest on loans, rather than fines and penalties, which will contribute to the restoration of banking assets by more than 42 billion drams and accelerate the financial turnover of commercial banks.

The variety of approaches demonstrates differences in perceptions regarding the levels of risks and their consequences for banking. Based on the data of the Statistical Bulletin of the National Bank of the Republic of Belarus, various indicators are used to analyze and assess the quality of bank assets (table 3). 
ENTREPRENEURSHIP AND SUSTAINABILITY ISSUES

ISSN 2345-0282 (online) http://jssidoi.org/jesi/

2020 Volume 7 Number 4 (June)

http://doi.org/10.9770/jesi.2020.7.4(47)

Table 3. Quality assets of Banks in the Republic of Belarus

\begin{tabular}{|l|c|c|}
\hline \multicolumn{1}{|c|}{ Name of indicator } & 2016 & 2017 \\
\hline $\begin{array}{l}\text { Debt on loans by banks of the Republic of Belarus by sector of the } \\
\text { economy (million rubles) }\end{array}$ & 35851,0 & 38762,5 \\
\hline $\begin{array}{l}\text { Overdue and prolonged debt on loans issued by banks of the } \\
\text { Republic of Belarus to the economic sector (mln. Rubles) }\end{array}$ & 1422,4 & 1474,7 \\
\hline $\begin{array}{l}\text { The share of overdue and prolonged debt on loans issued by banks of } \\
\text { the Republic of Belarus to the economic sector (\%) }\end{array}$ & 4,0 & 3,8 \\
\hline
\end{tabular}

The deterioration in the quality of bank assets stopped due to the fact that the growth of distressed assets was restrained by clearing the balances of large state-owned banks. The "bad" assets of state-owned banks were either transferred to a specially created agency, or transformed into the bond debt of the Ministry of Finance of Belarus and local authorities.

Indeed, the proportion of troubled assets of Belarusian banks from January 1, 2017 to January 1, 2018 increased slightly - from $12.79 \%$ to $12.85 \%$. However, in the context of various groups of banks, the dynamics of "ballast" differed sharply. Thus, the share of distressed assets among state banks in 2017 jumped from $12.71 \%$ to $14.94 \%$. In banks with foreign and private capital, the share of non-performing assets decreased from $13.29 \%$ to $9.05 \%$ and from $9.40 \%$ to $7.33 \%$, respectively. If we measure the deterioration in the quality of assets of state-owned banks in money rather than shares, then their volume of distressed assets increased by BYN 0.7 billion. Interestingly, in parallel, the size of distressed assets of large banks increased by almost the same amount.

The share of non-performing assets of large banks increased from $12.96 \%$ to $13.40 \%$, while that of medium and small banks decreased. According to the NBRB classification, 3 state banks are classified as large. Apparently, their asset quality deteriorated. The largest state-owned banks in Belarus are Belarusbank, Belagroprombank and Belinvestbank.

A decline in the quality of assets could happen both for all of them, and for one or two. In total, as of January 1 , 2018, state-owned banks concentrated 4.2 billion BYN of distressed assets, and large banks - 5.1 billion BYN. At the same time, the total volume of non-performing assets of 24 operating banks was 5.5 billion BYN.

Banks of Belarus had troubled assets both in Belarusian rubles (1.9 billion BYN) and in foreign currency (3.6 billion BYN). The share of troubled assets in BYN rubles for 2017 as a whole in the system fell from $12.41 \%$ to 9.62\%. Improved asset quality was observed across all groups of banks. Things were completely different with distressed assets accumulated in foreign currency. Their share in the system as a whole increased - from $13.05 \%$ to $15.66 \%$.

On a monthly basis, the Statistical Bulletin of the National Bank of the Republic of Belarus publishes data on the volume of debt on loans and other active operations, including prolonged and past due, which can be perceived as distressed assets. Debt detailing is carried out in the context of types of loans (short-term, long-term), groups of currencies (national, foreign), types of counterparties (customers, other banks) and sectors of the economy (state, private, individuals, and non-bank financial institutions). For example, data from the specified source allows us to assess the dynamics of the following indicators for 2017. 
In addition, the Republic of Belarus used an alternative approach to identifying distressed assets. It is presented in the Methodological comments on the indicators of analytical tables and charts of the information collection "Banking Sector of the Republic of Belarus.

In accordance with this approach, distressed assets included: assets exposed to credit risk, classified according to risk groups III - V in accordance with the Regulations on the Procedure for Formation and Use by Banks, Open Joint Stock Company "Development Bank of the Republic of Belarus" and Non-Bank Credit and Financial Organizations Special reserves to cover potential losses on assets and operations not reflected on the balance sheet approved by the resolution of the Board of the National Bank of the Republic of Belarus of September 28, 2006 138 (hereinafter - the instruction №138) (Resolution of the Board of the National Bank of the Republic of Belarus, 2006).

Information on assets subject to credit risk includes: loans issued to legal entities and individuals; funds placed in other banks; financial rent (leasing); operations using bills, purchased bills; executed bank guarantees and guarantees in cash; financing against the assignment of a monetary claim (factoring); other active operations subject to credit risk.

The data will allow you to analyze bad debts on assets exposed to credit risk and determine its share in their total volume. The table below contains information on the share of distressed assets in the banking sector of the Republic of Belarus (Table 4) (Information collection "Banking sector of the Republic of Belarus).

Table 4. Information on the share of distressed assets in the banking sector of the Republic of Belarus

\begin{tabular}{|l|c|c|}
\hline \multicolumn{1}{|c|}{ Name of indicator } & 2016 & 2017 \\
\hline Banking sector assets exposed to credit risk (mln. Rubles) & 40182,6 & 43177,1 \\
\hline Distressed banking sector assets exposed to credit risk (mln rubles) & 5139,8 & 5549,2 \\
\hline $\begin{array}{l}\text { The share of troubled banking sector assets exposed to credit risk in the } \\
\text { total volume of banking sector assets exposed to credit risk (\%) }\end{array}$ & 12,79 & 12,85 \\
\hline
\end{tabular}

Source: compiled by authors according to Information collection "Banking sector of the Republic of Belarus

Credit indebtedness of organizations and legal entities increased by $5.9 \%$ over the past 12 months, it is encouraging that bad debt decreased by $9.8 \%$ over the same period of time (Table 5) (www.infobank.by ).

Table 5. Credit indebtedness of resident organizations and resident individuals, million rubles

\begin{tabular}{|l|c|c|c|c|c|}
\hline \multicolumn{1}{|c|}{ Indicator } & 01.07 .2017 & 01.04 .2018 & 01.07 .2018 & \multicolumn{2}{c|}{ Changes } \\
\cline { 3 - 6 } & & & & $\begin{array}{c}\text { For 3 } \\
\text { months }\end{array}$ & $\begin{array}{c}\text { For } 12 \\
\text { months }\end{array}$ \\
\hline \multicolumn{7}{|c|}{ Credit debt of resident organizations } \\
\hline Credit debt & 27271,3 & 28455,5 & $28,877,5$ & $1,5 \%$ & $5,9 \%$ \\
\hline in\% to assets & 43,99 & 44,45 & 45,08 & 0,63 & 1,08 \\
\hline Bad credit debt & 1815,1 & 1802,3 & 1636,9 & $-9,2 \%$ & $-9,8 \%$ \\
\hline$\%$ to credit debt & 6,6 & 6,33 & 5,67 & $-0,67$ & $-0,99$ \\
\hline \multicolumn{7}{|c|}{ Credit indebtedness of resident individuals } \\
\hline Credit debt & 7648,9 & 9497,0 & 10143,7 & $6,8 \%$ & $32,6 \%$ \\
\hline in\% to assets & 12,34 & 14,84 & 15,83 & 1 & 3,5 \\
\hline Bad credit debt & 46,9 & 45,0 & 48,9 & $8,6 \%$ & $4,2 \%$ \\
\hline$\%$ to credit debt & 0,61 & 0,47 & 0,48 & 0,01 & 0,13 \\
\hline
\end{tabular}


Table 6 provides information on the share of troubled assets exposed to credit risk provided to legal entities and individuals by banks of the Republic of Belarus (Information collection "Banking sector of the Republic of Belarus)

Table 6. Information on the proportion of distressed assets exposed to credit risk

\begin{tabular}{|l|c|c|}
\hline \multicolumn{1}{|c|}{ Name of indicator } & 2016 & 2017 \\
\hline $\begin{array}{l}\text { Assets exposed to credit risk provided by legal entities and } \\
\text { individuals (mln. Rubles) }\end{array}$ & 34808,5 & 37992,2 \\
\hline $\begin{array}{l}\text { Distressed assets exposed to credit risk provided to legal entities } \\
\text { and individuals (mln rubles) }\end{array}$ & 5139,8 & 5549,2 \\
\hline $\begin{array}{l}\text { The share of troubled assets exposed to credit risk provided to legal } \\
\text { entities and individuals in the total volume of assets exposed to } \\
\text { credit risk provided to legal entities and individuals (\%) }\end{array}$ & 14,6 & 14,4 \\
\hline
\end{tabular}

In April 2018, a new version of Instruction No. 138 entered into force in the Republic of Belarus. In accordance with it, the number of risk groups for which the classification of assets exposed to credit risk is carried out in order to create a special reserve increased from 5 to 6 . In addition, the concept of "Maintenance-free assets" (NPL) was legislatively enshrined. This indicator is traditionally used in foreign practice when assessing the value of bad credit debt and troubled assets of banks. In accordance with the norms enshrined in the new edition of Instruction No. 138, non-performing assets include:

- assets for which overdue from 8 to 90 days were formed for which there is no collateral;

- debt overdue from 8 to 90 days for which there is no collateral;

- restructured debt in IV-VI risk groups;

- debt on funds in other banks, overdue from 31 days to 90 days;

- debt of debtors in respect of which bankruptcy proceedings have been opened, liquidated, declared bankrupt;

- indebtedness upon the occurrence of force majeure circumstances specified in the contract, which caused damage to the debtor, preventing him from continuing his activities.

These approaches are quite new. The lack of relevant statistics does not allow us to estimate the size of nonserviced assets (NPL) in the Republic of Belarus at the moment (Information collection "Banking sector of the Republic of Belarus).

Table 7. Dynamics of indicators of development of the banking sector of the Republic of Belarus for 2018

\begin{tabular}{|l|l|c|c|c|}
\hline$№$ & Name of indicator & $\begin{array}{c}\text { Unit of measurement } \\
\text { (in national currency) }\end{array}$ & 01.01 .18 & 01.03 .18 \\
\hline 1 & Number of existing credit organizations (KO) & units & 24 & 24 \\
\hline 2 & The number of corporate bonds with foreign participation & units & 20 & 20 \\
\hline 2.1 & - including with 100\% share of foreign capital & units & 5 \\
\hline 3. & The number of branches of operating KO & million rubles & 9631,4 & 9811,2 \\
\hline 4. & Own funds (capital) KO & million rubles & 66679,6 & 65955,0 \\
\hline 5. & Assets TO (total) & million rubles & 38762,5 & 38934,8 \\
\hline 5.1 & - loan debt (total) & million rubles & 1474,7 & 1327,3 \\
\hline 5.1 .1 & - including prolonged and past due & million rubles & 9031,9 & 9327,8 \\
\hline 5.2 & - loans granted to individuals & & 34 \\
\hline
\end{tabular}




\section{ENTREPRENEURSHIP AND SUSTAINABILITY ISSUES}

ISSN 2345-0282 (online) http://jssidoi.org/jesi/

2020 Volume 7 Number 4 (June)

http://doi.org/10.9770/jesi.2020.7.4(47)

\begin{tabular}{|l|l|c|c|c|}
\hline 5.3 & - loans to private ownership & million rubles & 15619,8 & 15693,0 \\
\hline 6 & Liabilities KO (total) & million rubles & 66679,6 & 65955,0 \\
\hline 6.1 & Deposits of individuals & million rubles & 22029,2 & 22005,8 \\
\hline 6.2 & $\begin{array}{l}\text { Resources attracted by credit organizations in the interbank } \\
\text { market }\end{array}$ & million rubles & 1878,9 & 1540,4 \\
\hline 7 & Financial result of the banking sector & million rubles & 886,7 & 127,8 \\
\hline 8 & Minimum amount of capital for existing credit organizations & million rubles & 51,71 & 52,75 \\
\hline 9 & Refinancing rate (key rate) of the National Bank & 11,0 & 10,5 \\
\hline & For reference: & $\begin{array}{l}|c| \\
\text { billion rubles } \\
\text { dollar }\end{array}$ & 1,9727 & 1,9537 \\
\hline 11 & Gross Domestic Product (January - February 2018) & National Currency to US Dollar & BS & 17,2 \\
\hline
\end{tabular}

Source: compiled by authors according to Information collection "Banking sector of the Republic of Belarus

Next, we consider the situation with lending in the Republic of Kazakhstan, where as of April 1, 2018, the loan portfolio (main debt) of the banking sector of the Republic of Kazakhstan amounted to 13,306.3 billion tenge. Overdue loans amounted to $16.4 \%$ (2,181.4 billion tenge) of the loan portfolio, while loans overdue for more than 90 days (NPL) amounted to $10.01 \%$ (1,331.6 billion tenge).

Despite the current level of non-performing loans in the loan portfolio of banks, the adjustment of the tenge and the deterioration of macroeconomic conditions (lower prices for the main export positions of the country) have reduced the creditworthiness of most banks' clients. So, a survey of large enterprises in the real sector of the economy shows:

1) Decrease in economic activity in $2015-2017$;

2) Deterioration of the financial and economic state of enterprises.

Accordingly, maintaining a high level of problem loans on the balance sheet of banks continues to be one of the main problems restraining lending activity of banks. Recent surveys of the credit market show that despite the created conditions for improving the loan portfolio, most banks do not expect a significant improvement in the quality of the loan portfolio. So, in the 1st quarter of 2018 , more than $65.6 \%$ of banks predict that the quality of the loan portfolio will remain unchanged, $12.5 \%$ of respondents expect deterioration and $21.9 \%$ of some improvement in the quality of the loan portfolio.

The deterioration in the quality of the loan portfolio leads to a decrease in the risk of appetite among banks; one hundred is confirmed by the low level of approval of loan applications. Most banks do not forecast an increase in the number of approved loan applications. The loan portfolio for the first quarter of 2018 decreased by 285.3 billion tenge.

The instability of the financial condition of borrowers, a significant decrease in the rate of repayment of overdue debts due to a drop in demand for the purchase of collateral at current market prices, the high cost of funding in the national currency for banks, the revaluation of the foreign currency of the loan portfolio leads to an increase in non-performing loans and puts pressure on banks' capital.

At the same time, the real level of non-performing loans and their write-off for the balance sheet. Given the slowdown in economic growth, restructuring, in fact, has become the only available tool for banks to reduce the debt burden on borrowers. 


\section{ENTREPRENEURSHIP AND SUSTAINABILITY ISSUES}

ISSN 2345-0282 (online) http://jssidoi.org/jesi/

2020 Volume 7 Number 4 (June)

http://doi.org/10.9770/jesi.2020.7.4(47)

Under these conditions, the potential volume of non-performing loans may be higher. The National Bank of the Republic of Kazakhstan conducted a selective analysis of the largest loans in the banking system, which showed that the amount of potential NPL, taking into account the restructured loans, is about $25 \%$ of the banks' portfolio. The problem of a high level of non-performing loans is aggravated by the low quality of banks' collateral in the form of property and money coming in the future, insurance contracts that have many reasons for refusing insurance payments; guarantees of individuals and small enterprises. In individual banks, the share of such loans exceeds $80 \%$ of their loan portfolio. It is widely practiced by individual banks to provide loans to persons who, from the point of view of the law, do not directly have signs of connectedness, but are indirectly associated with shareholders or officials of the bank. Some of these loans are non-repayable.

The dynamics of loans with overdue over 90 days (NPL) for the period from the beginning of the crisis to the present in the banking sector of the Republic of Kazakhstan are given below (figure 1).

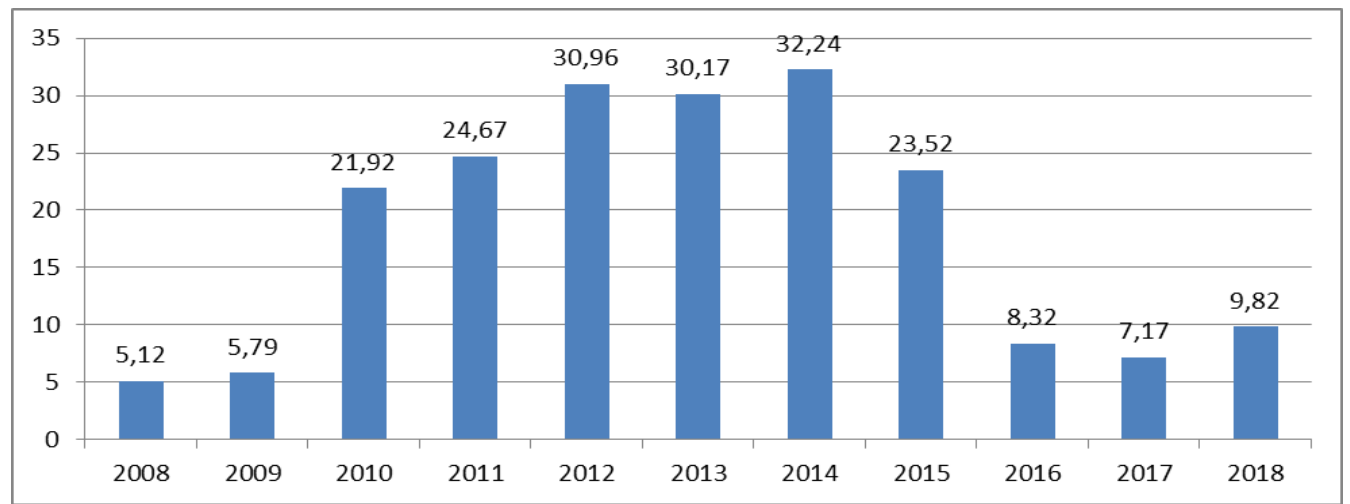

Figure 1. Dynamics of loans overdue by more than 90 days (NPL) in the Republic of Kazakhstan (\%) for the period from $2008-2018$. Source: compiled by authors according to the source www.afk.kz

Bad loans with delinquencies of more than 90 days in the system make up $10.0 \%$ of the total loan portfolio $(9.3 \%$ at the beginning of the year). Thus, the growth of recognition of problem loans continues. At the same time, the level of provisioning in the sector showed some growth: the formed provisions in the system increased by 24.6 billion tenge $(+1.2 \%)$ to 2.2 trillion tenge or $161.5 \%$ of NPL coverage $(90+)$. Provisions are growing amid banks recognition of bad debt on the balance sheets.

Freezing and delaying the solution of the above problems to a later date, as was observed in previous years, leads to a significant increase in systemic risks in the banking sector. The dissemination of these practices has become possible due to many institutional weaknesses associated with the low responsibility of auditors and appraisers for the quality of reporting, the abolition of supervisory judgments in assessing credit risk and the increasing role of banks themselves in forming provisions in accordance with IFRS.

One of the pressing problems in ensuring the stable functioning of the financial system is the development and use of effective measures to clean bank balance sheets from loans with late payments over 90 days.

The situation with ensuring the quality and optimal structure of loan portfolios of Kazakhstan banks has not changed over the past few years. The practice of developed countries in solving the problem of "bad" loans shows that without an active policy and support from the state, the solution of the issue of "idle" loans can reduce the competitiveness of the banking sector of Kazakhstan, including in integration processes within the framework of the Single Economic Union, and resistance to possible future shocks in world markets (Data of the National Bank of the Republic of Kazakhstan) (table 8). 


\section{ENTREPRENEURSHIP AND SUSTAINABILITY ISSUES}

ISSN 2345-0282 (online) http://jssidoi.org/jesi/

2020 Volume 7 Number 4 (June)

http://doi.org/10.9770/jesi.2020.7.4(47)

Table 8. Dynamics of indicators of development of the banking sector of the Republic of Kazakhstan for 2017-2018

\begin{tabular}{|c|c|c|c|c|c|}
\hline № & Name of indicator & $\begin{array}{l}\text { Unit of } \\
\text { measurement (in } \\
\text { national currency) }\end{array}$ & 2016 & 2017 & $\begin{array}{l}\text { First quarter } \\
\text { of } 2018\end{array}$ \\
\hline 1 & $\begin{array}{l}\text { Number of existing credit organizations } \\
\text { (KO) }\end{array}$ & units & 33 & 32 & 32 \\
\hline 2 & $\begin{array}{l}\text { The number of corporate bonds with } \\
\text { foreign participation }\end{array}$ & units & 15 & 13 & 13 \\
\hline 2.1 & $\begin{array}{l}\text { - including with } 100 \% \text { share of foreign } \\
\text { capital }\end{array}$ & units & 11 & 11 & 11 \\
\hline 3. & Number of branches of operating KO & units & 349 & 333 & 331 \\
\hline 4. & Own funds (capital) KO & billion tenge & 2840,6 & 3029,7 & 3077,6 \\
\hline 5. & CO assets - total & billion tenge & 25556,8 & 24157,9 & 23768,7 \\
\hline 5.1 & Loan debt & billion tenge & 15510,8 & 13590,5 & 13306,3 \\
\hline 5.1 .1 & including overdue & billion tenge & 1042,1 & 1265,2 & 2181,4 \\
\hline 5.2 & Loans to individuals & billion tenge & 3766,6 & 4259,1 & 4492,2 \\
\hline 5.3 & Loans to non-financial organizations & billion tenge & 11712,1 & 9285,1 & 8766,0 \\
\hline 5.3 .1 & Including: loans to small businesses & billion tenge & 5002,0 & 4664,5 & 3038,7 \\
\hline 5.4 & $\begin{array}{l}\text { Loans to banks and organizations engaged } \\
\text { in certain types of banking operations }\end{array}$ & billion tenge & 32,1 & 46,3 & 48,1 \\
\hline 6 & Liabilities KO (total) & billion tenge & 22716,2 & 21128,2 & 20691,1 \\
\hline 6.1 & Customer deposits, total & billion tenge & 17268,6 & 16680,5 & 16443,8 \\
\hline \multirow[t]{4}{*}{6.1 .1} & Including: & billion tenge & 7144,8 & 7383,6 & 7266,4 \\
\hline & - deposits of individuals & billion tenge & 5456,6 & 4745,0 & 5089,4 \\
\hline & - deposits of legal entities & billion tenge & 772,8 & 843,3 & 821,4 \\
\hline & - current accounts of individuals & billion tenge & 3894,4 & 3708,6 & 3266,6 \\
\hline 6.2 & - current accounts of legal entities & billion tenge & 418,3 & 315,6 & 329,7 \\
\hline 6.3 & Interbank deposits & billion tenge & 956,4 & 608,9 & 645,1 \\
\hline 6.4 & $\begin{array}{l}\text { Loans received from other banks and } \\
\text { organizations engaged in certain types of } \\
\text { banking operations }\end{array}$ & billion tenge & 227,5 & 150,6 & 145,8 \\
\hline 6.5 & $\begin{array}{l}\text { Loans received from international financial } \\
\text { organizations }\end{array}$ & billion tenge & 52,5 & 54,0 & 61,9 \\
\hline 6.6 & Securities issued & billion tenge & 1778,1 & 1321,1 & 2005,6 \\
\hline 6.7 & Securities Repo & billion tenge & 432,7 & 406,0 & 229,0 \\
\hline 6.8 & Other liabilities & billion tenge & 1582,1 & 1591,5 & 830,2 \\
\hline 7 & Financial result of the banking sector & billion tenge & 397,6 & $-62,3$ & 214,3 \\
\hline \multirow[t]{2}{*}{8} & $\begin{array}{l}\text { Minimum amount of capital for existing } \\
\text { credit organizations }\end{array}$ & billion tenge & 10,0 & 10,0 & 10,0 \\
\hline & For reference: & & & & \\
\hline 9 & Base (key) rate of the NBK & $\%$ annual & 12,0 & 10,25 & 9,25 \\
\hline 10 & Gross Domestic Product per year & billion tenge & $\begin{array}{c}46971,2 \\
\text { (estimation) }\end{array}$ & $\begin{array}{c}51566,8 \\
\text { (estimation) }\end{array}$ & $\begin{array}{l}55906,2 \\
\text { (forecast) }\end{array}$ \\
\hline 11 & National Currency to US Dollar & tenge & 333,29 & 332,33 & 318,31 \\
\hline
\end{tabular}

Source: compiled and calculated by authors 


\section{ENTREPRENEURSHIP AND SUSTAINABILITY ISSUES}

ISSN 2345-0282 (online) http://jssidoi.org/jesi/

2020 Volume 7 Number 4 (June)

http://doi.org/10.9770/jesi.2020.7.4(47)

According to the NBK, in January-February 2018 new loans were issued for 1.7 trillion tenge, which is 424.1 billion tenge $(+33 \%)$ more than in the same period last year. At the same time, according to the results of January-March 2018, the second-tier banks' loan portfolio decreased by 284.2 billion tenge (-2.1\%) to 13.3 trillion tenge. We note that the share of the loan portfolio in total assets at the beginning of April was 56\%, whereas a year earlier it was $60.9 \%$.

On April 16, the NBK announced another reduction in the base rate to $9.25 \%$ with a $+/-1 \%$ corridor, which led to a drop in the country's money market near the lower limit of the interest corridor (TONIA 8.3\%, SWAP 8.38\%), and the yield of weekly notes decreased to $8.35 \%$ per annum. If this trend continues, banks will have more motivation to redirect free liquidity to lending. We note that the volume of notes in circulation at the end of March was close to 4.2 trillion tenge (current 4.1 trillion tenge) or about $32 \%$ of the loan portfolio of the system. At that, a year earlier, the total volume of notes was close to 3.3 trillion tenge or $21.7 \%$ of the total loan portfolio.

The maximum increase in the loan portfolio in absolute terms since the beginning of the year is observed at BCC, whose portfolio since the beginning of the year increased by $6.6 \%$ or 60.9 billion tenge. At the same time, KKB showed the maximum decrease in the loan portfolio - minus 169.9 billion tenge (-10.4\%) to 1.4 trillion tenge.

The share of loans in foreign currency in January-March tenge decreased by $1.2 \%$, amounting to 3.2 trillion tenge or $25.1 \%$ of total loans to the economy. In March, the weighted average interest rate on loans issued in national currency to legal entities amounted to $12.8 \%$ (13.2\% at the beginning of the year), to individuals - 19.6\% (19.2\%). The increase in interest rates on loans to the population, including due to the continuing tangible credit risk in relation to the retail segment.

The share of all overdue loans in the system for the first quarter of 2018 increased from $14.6 \%$ to $16.4 \%$. Bad loans with delinquencies of more than 90 days in the system make up $10.0 \%$ of the total loan portfolio (9.3\% at the beginning of the year). Thus, the growth of recognition of problem loans continues. At the same time, the level of provisioning in the sector showed some growth: the formed provisions in the system increased by 24.6 billion tenge $(+1.2 \%)$ to 2.2 trillion tenge or $161.5 \%$ of NPL coverage (90+). Provisions are growing amid banks recognizing bad debts on the balance sheets (Association of Banks of the Republic of Kazakhstan "The Problem of Bad and Bad Credit - NPL: as of April 1, 2018, 2018).

Drawing conclusions, the volume of toxic loans with delays of more than 90 days, according to ranking.kz, for the year declined immediately by $29 \%$, and the volume of loans with late payments decreased by $56.4 \%$. The numbers inspire some hope, but I would not be in a hurry to do far reaching conclusions from this. In the last year or two, the situation on the credit market of Kazakhstan looks uneven. So, in the first half of 2017, there was a high growth in lending against the backdrop of a high level of toxic loans - in some banks it exceeded $90 \%$. The state was forced to take measures, and last year the National Bank began to implement the Program to increase the financial stability of the banking sector. It was designed to improve the banking sector, reduce the level of nonperforming loans and help create the conditions for economic growth. Within its framework, five largest banks received assistance, accounting for more than $30 \%$ of the loan portfolio of the entire banking system.

In addition, the effects of the introduction of IFRS 9 in the country, which entered into force on January 1, 2018, are felt - they demanded a more thorough assessment of risks from banks, since now they have to take into account expected credit losses, rather than actually incurred, as before. As a result, banks are forced to limit the supply of high-risk products, refuse high-risk borrowers and more accurately evaluate the credit rating of customers - otherwise this is fraught with deterioration of assets and sanctions by the regulator. By the way, these measures affected not only a decrease in toxic loans, but also a slight decline in lending - the loan portfolio of the second-tier banks of the Republic of Kazakhstan at the end of the first half of 2018 amounted to 13.5 trillion tenge, which is $13.2 \%$ less than in the past year, while in the minus were 10 STB out of 32. 


\section{ENTREPRENEURSHIP AND SUSTAINABILITY ISSUES}

ISSN 2345-0282 (online) http://jssidoi.org/jesi/

2020 Volume 7 Number 4 (June)

http://doi.org/10.9770/jesi.2020.7.4(47)

Therefore, the decrease in the volume of "bad" loans is due to the fact that the principles of banks are changing, which allow not to allow a high level of toxic loans, and these actions undoubtedly bring effect, as the numbers show. And yet it's too early to talk about stable long-term results, especially since international rating agencies are cautious in their assessments: for example, Fitch talks about the still poor quality of assets, noting, however, that the regulator's tolerance for problem loans has become much lower.

Considering bad loans in Kyrgyzstan, I would like to note that since January 2018, International Financial Reporting Standards (IFRS) 9 came into force in Kyrgyzstan, according to which commercial banks should take into account expected credit losses, but not actually incurred, as required by IFRS 39. The republic's commercial banks are responsible for predicting the solvency of their customers, calculating expected losses, and creating reserves for the entire duration of the product. Banks may face:

- lack of historical statistics for calculations;

- lack of staff with the necessary skills or trainees;

- toughness of information systems to the automation of new approaches to the calculation of reserves.

At the same time, the transition to IFRS 9 will not make adjustments to the business plans of banks, but standards may affect the level of lending to the economy in the near future. Growth in lending to high-risk borrowers is not expected. Perhaps, there will be a reduction in the terms of lending for individual products, which is associated with the peculiarities of assessing the probability of default. IFRS 9 is expected to create a burden on the profitability of banks, since the assessment of estimated losses entails a greater amount of reserve funds, which creates a burden on capital and reduces profitability. IFRS 9 requires a fundamentally different work with risks. The banking sector of Kyrgyzstan has a sufficient level of KGS liquidity. Between 2010 and 2017, there was a dynamic increase in the volume of loans in the banking system of Kyrgyzstan. In January-March 2018, the total loan portfolio of commercial banks increased by $2.1 \%$, reaching 110.6 billion soms. Catfish loans increased by $1.2 \%$ - up to 68 billion soms. According to the National Bank, the weighted average interest rate on all loans decreased from $16 \%$ to $15.5 \%$, for som - from $18.8 \%$ to $18.5 \%$. Table 9 shows the consolidated statement of profit (Data of the National Bank of Kyrgyzstan for the period from 2014-2018).

Table 9. The consolidated statement of profit / loss of commercial banks in Kyrgyzstan

\begin{tabular}{|c|c|c|c|c|c|}
\hline & 2014 & 2015 & 2016 & 2017 & 2018 \\
\hline \multicolumn{6}{|c|}{ A. Profit / loss statement of commercial banks } \\
\hline Total interest income & 13381519 & 19300445 & 19570080 & 19497034 & 21256946 \\
\hline Total interest expense & 5087382 & 8924835 & 9498234 & 7681966 & 7534606 \\
\hline Net interest income & 8294137 & 10375610 & 10071845 & 11815068 & 13722341 \\
\hline $\begin{array}{l}\text { Allowance for potential losses and } \\
\text { losses on loans }\end{array}$ & 544963 & 1430547 & 1400026 & 611900 & 1379990 \\
\hline $\begin{array}{l}\text { Net interest income after deductions } \\
\text { to RPPU }\end{array}$ & 7749174 & 8945062 & 8671820 & 11203167 & 12342350 \\
\hline Total non-interest income & 5850866 & 12143904 & 14630679 & 10007335 & 11026503 \\
\hline Total non-interest expenses & 1572728 & 7801601 & 10603234 & 5733925 & 6096372 \\
\hline $\begin{array}{l}\text { Total other operating and } \\
\text { administrative expenses }\end{array}$ & 8216751 & 10406591 & 11241612 & 12507304 & 13455908 \\
\hline Net operating income (loss) & 3810560 & 2880775 & 1457652 & 2969274 & 3816574 \\
\hline
\end{tabular}


ENTREPRENEURSHIP AND SUSTAINABILITY ISSUES

ISSN 2345-0282 (online) http://jssidoi.org/jesi/

2020 Volume 7 Number 4 (June)

http://doi.org/10.9770/jesi.2020.7.4(47)

\begin{tabular}{|l|c|c|c|c|c|}
$\begin{array}{l}\text { Provisions for potential losses and } \\
\text { losses (not from credit operations) }\end{array}$ & 244442 & 212393 & 424647 & 481314 & 356304 \\
\hline Net income (loss) before tax & 3566119 & 2668382 & 1033006 & 2487960 & 3460270 \\
\hline Income tax & 396425 & 302541 & 178562 & 349532 & 456796 \\
\hline Net income (loss) & 3169694 & 2365842 & 854443 & 2138428 & 3003473 \\
\hline \multicolumn{7}{|c|}{ B. Classification } \\
\hline
\end{tabular}

Source: compiled and calculated by authors according to Data of the National Bank of Kyrgyzstan for the period from $2014-2018$

The volume of the loan portfolio of the banking sector as of September 30, 2018 amounted to KGS 123.9 billion, having increased by 14.4 percent since the beginning of the year (KGS 108.3 billion at the end of 2017).

In the loan portfolio of the banking system as a whole, the share of classified loans as of September 30, 2018 amounted to 7.4 percent or 9.1 billion soms (as of the end of $2017-7.6$ percent or 8.2 billion soms).

The indicator of the net total capital of the banking sector, used to calculate the economic standards established by the National Bank, amounted to KGS 35.5 billion as of September 30, 2018, having increased by 5.7 percent since the beginning of the year (KGS 33.6 billion at the end of 2017).

Since the middle of 2013, in the banking system of the republic there has been a gradual increase in unclassified loans of the "under supervision" group, and since the beginning of 2014, there has been a sharp decrease in the performance of the "satisfactory loans" group and an almost twofold increase in the number of "qualified loans". In the period from 2014 to 2016, there was a decrease in the profitability of the banking system as a whole, with a subsequent recovery along with an increase in lending to agriculture, industry and consumer loans.

This dynamics of decline in financial sector indicators is explained by the increase in bank expenses on loans and the obligatory "nest egg", deferred to cover possible losses.

GDP growth Interest rates on loans are the most significant explanatory indicators of macroeconomic activity (GDP, production, unemployment, investments) and the exchange rate significantly affect the stability of the banking sector.

Under the conditions of the Kyrgyz economy, GDP growth has a statistically significant effect on the decline in the share of classified indicators. Since 2016, the volume of problem loans in the loan portfolio has ceased to increase actively and this is due to the adopted micro-prudential measures and de-dollarization measures, the transformation of foreign currency loans into som, and an increase in the minimum authorized capital of banks.

The National Bank of the Kyrgyz Republic in its policy actively uses financial instruments to maintain the required amount of cash in the market, stimulate the economy, and reduce the discount rate in order to reduce the cost of financial resources. The discount rate is tied to inflation indicators. 


\section{ENTREPRENEURSHIP AND SUSTAINABILITY ISSUES}

ISSN 2345-0282 (online) http://jssidoi.org/jesi/

2020 Volume 7 Number 4 (June)

http://doi.org/10.9770/jesi.2020.7.4(47)

A high weighted average interest rate on loans will not be lower depending on the resource base being formed, in particular, deposit rates are about $10-12 \%$, in addition to which include credit risks, operating expenses, a small profit margin. Commercial banks do not have subsidized funds, so the interest rate is formed by the market mechanism.

The resource base of commercial banks is formed by international lenders and depositors. A country credit rating is not in favor of attracting cheap long-term funds from foreign markets to the republic's banking system.

The global financial crisis had an impact on the economies of the nearest neighbors and major trading partners, on the state of the exchange rates of the national currencies of neighboring states - Russia and Kazakhstan, on the availability of external funding, the cost of money, which had an impact on the consumer demand of the population, formed negative economic expectations for Entrepreneurs of Kyrgyzstan, reduced interest in business activity, led to an expected position.

Against this background of a decline in business activity, a decrease in the solvency of debtors is observed. If earlier they managed to accumulate money and repay loans on a monthly basis, then in the emerging economic situation they fell into the category of problem borrowers, and the share of satisfactory loans fell sharply. For this reason, interest and non-interest expenses of banks grew, profitability indicators decreased.

As a result of reduced economic activity, the profitability of the corporate sector and the household sector is reduced; unemployment is growing, which leads to a decrease in the quality of the banks' loan portfolio. Sectors of the economy of the republic actively credited by the banking system such as construction, trade, real estate also showed a decrease in profitability.

The situation of slowdown in business activity forced banks to more carefully select lending facilities. At the same time, interest rates in national and foreign currencies began to decline, which affected the interest rates on deposits downward.

With a low level of remuneration, part of the population does not stop the risk of a possible non-repayment of a bank loan. According to a survey conducted by the Legal Perspective Public Foundation in ayil aimakhs in southern Kyrgyzstan, more often women over 25 take loans and not at all for starting a business. Men rarely take loans because they fear the loss of real estate, as well as the likelihood of putting their own family in a difficult position.

If we consider lending in microcredit organizations, the main users are rural residents. Unemployment forces people to take loans for household and family expenses. Family breadwinners often go abroad to earn money to pay off arrears.

Before making a decision on granting a loan, any bank turns to CIB "Ishenim" for information that shows the credit discipline of a potential borrower. If delays are recorded in the CIB, the borrower has a bad credit history. This gives the bank a reason to refuse to grant a loan in accordance with internal procedures. In many countries, debtors are not released from the country. In Kyrgyzstan, this is not practiced.

From the practice of a bank's loyalty to repaying a loan, one can note the fact that the terms of existing loan agreements by banks are not being reviewed. There were no cases of refusal to recover debt from the bank when livestock bought on credit died, but banks were more likely to repay loans when there were real facts of the death of borrowers or the complete destruction of the property that was in the mortgage. 


\section{ENTREPRENEURSHIP AND SUSTAINABILITY ISSUES}

ISSN 2345-0282 (online) http://jssidoi.org/jesi/

2020 Volume 7 Number 4 (June)

http://doi.org/10.9770/jesi.2020.7.4(47)

Some experts believe that the government needs to consider not only the interests of borrowers, but also lenders. If borrowers do not have the skills of competent financial distribution and targeted spending, then this is the fault of the citizens themselves. But there are objective conditions that make it difficult for borrowers to access information. For example, until 2014, the text of the contract with the bank was written only in Russian, while the Kyrgyz-speaking residents of the regions were actively using loans.

In practice, there was a situation where bank employees resorted to unconventional methods of stimulating the repayment of borrowed funds by contacting the heads (akims) of the village council with a request to influence a resident of a given territorial area. There have been cases when aksakals appealed to the courts with a request to exert an effect on the repayment of the existing debt of a local resident.

The existing experience in working with credit risks against the backdrop of new international requirements is updating the skills of forecasting credit risks and generating the demand of the population, the banking sector and entrepreneurs for credit risk databases and related forecasting, consulting products. It seems true that this is the next institutional step for the economy of Kyrgyzstan.

Lending, as you know, the supporting structure of the banking system of Russia: the share of loans in the total assets of Russian banks is slightly less than $70 \%$. At the end of 2017, we can conclude that there are signs of a revitalization of the lending process: compared with 2016, there was an increase in the total volume of loan debt of non-financial organizations and the population.

The main contribution to the positive dynamics of lending was made by the retail segment. The fastest pace was the expansion of housing and mortgage lending, whose share in the total volume of loan debt of the population is approaching $45 \%$. This is a reflection of the recovery in consumer activity in the Russian economy and may be one of the main factors in GDP growth.

The dynamics of lending to non-financial organizations moved into the zone of positive values, but absolute volumes have not yet reached the 2015 level. The weak dynamics of corporate lending is based on several factors: - shortage of quality borrowers;

- the presence of a significant amount of bad and overdue debt required the formation of reserves, which over the past year increased by more than a quarter;

- the conditions of bank lending, despite their softening, have remained rather stringent both in interest rates and in terms of non-price characteristics.

During the recovery period after the crisis of 2007-2008 the Russian banking sector showed moderate dynamics of problem and bad loans, the share of overdue loans of non-financial organizations and individuals gradually decreased.

Since 2014, under the influence of the difficult macroeconomic situation and the high volatility of the exchange rate, the number of loans of IV and V quality categories in the loan portfolio began to increase sharply. Against the background of a significant increase in interest rates and a decrease in real disposable income, a jump in the share of overdue loans was observed.

The stabilization of the market situation in the middle of 2016 allowed slowing down the negative dynamics and reversing the trend. Moreover, the existing geo-economic uncertainty leaves its mark on the development trends of problem and bad loans in Russia.

The poor quality of portfolios creates barriers to the transition from moderately tight to neutral monetary policy. Clearing "bad" portfolios is a prerequisite for realizing the positive effects of softening the conditions of bank 


\section{ENTREPRENEURSHIP AND SUSTAINABILITY ISSUES}

ISSN 2345-0282 (online) http://jssidoi.org/jesi/

2020 Volume 7 Number 4 (June)

http://doi.org/10.9770/jesi.2020.7.4(47)

lending. But this means that the policy to free the banking sector from unscrupulous participants should reach a new level: the emphasis needs to be shifted to the prevention of banking risks, the assessment of the adequacy of the formation of RVPS and the compliance of the business models used by credit organizations with their capabilities.

In the first half of 2018, the main indicators of banks' activity were slowly growing, with the exception of the effect of currency revaluation. According to the Bank of Russia, the assets of the banking sector in the first half of 2018 increased by only $0.1 \%$. For comparison, the growth of assets in the 1 st half of 2017 amounted to $2.2 \%$. The Bank of Russia considers the main reason for the reduction in assets is the consolidation of the business of large banks and a decrease in their mutual interbank operations.

The total volume of loans to the economy (loans to enterprises and households) in the 1 st half of 2018 increased by $4.1 \%$, doubling in comparison with the indicator of the 1st half of 2017 (1.8\%). Including loans to enterprises increased by $1.8 \%$, and loans to individuals increased by $9.3 \%$. The Central Bank told how lending is growing in the context of the types of activities of enterprises-borrowers of banks. Over the past 1.5 years, agricultural lending, mining lending and trade lending have grown faster than the market. After a long recession, lending to construction resumed. Lending to the manufacturing industry after the recovery growth of 2017 slowed down. Banks again turned their attention to small business - in January-May 2018, the portfolio of loans to SMEs increased by $6.9 \%$. This is due to some improvement in the situation in the economy, which positively affects the incomes of the population - the main client of SMEs. Indeed, most small businesses operate in the field of trade and retail services.

In retail lending, the mortgage is growing steadily - in January-May 2018, the growth was $8.5 \%$. In the total volume of loans to the population, mortgage loans account for $43.2 \%$. At the same time, mortgage loans in rubles are the highest quality asset of banks, the delay on it is only $1.3 \%$.

The portfolio of unsecured consumer loans grew by 7\% in January-May 2018. The volume of car loans in January-May 2018 increased by 3.6\%.

On the whole, in the first half of 2018, the volume of overdue debts in the corporate portfolio increased by $7.9 \%$ in the banking system and decreased by $4.2 \%$ in the retail sector. The share of overdue loans to enterprises increased from $6.4 \%$ to $6.7 \%$, and for retail loans - decreased from $7 \%$ to $6.1 \%$.

The share of overdue debts in the total amount of loans, deposits and other placed funds of the banking sector as of 01.01.2017 increased from 3.8 to 5.2\% compared to 2015. By 2018, this indicator amounted to 5.16\%. It should be noted that the share of overdue loans and other funds provided to individual entrepreneurs is $15.2 \%$.

Assets of the banking sector, weighted by risk level, in 2018 are estimated at 77,884.2 billion rubles, of which the credit risk for assets reflected in balance sheet accounts is $42.9 \%$

As Tovpenko P.A. notes in his analysis, in 2017, a significant decrease is observed in the number of banks whose share of overdue debt did not exceed 5\% of the loan portfolio, from 508 to 272. However, in 60 banks, the proportion of overdue debt exceeds $60 \%$ and their number over 2 years increased by 34 . The number of credit institutions with no overdue debts amounted to 55 units as of 01.01.2017 (Tovpeko, 2018) (figure 2). 


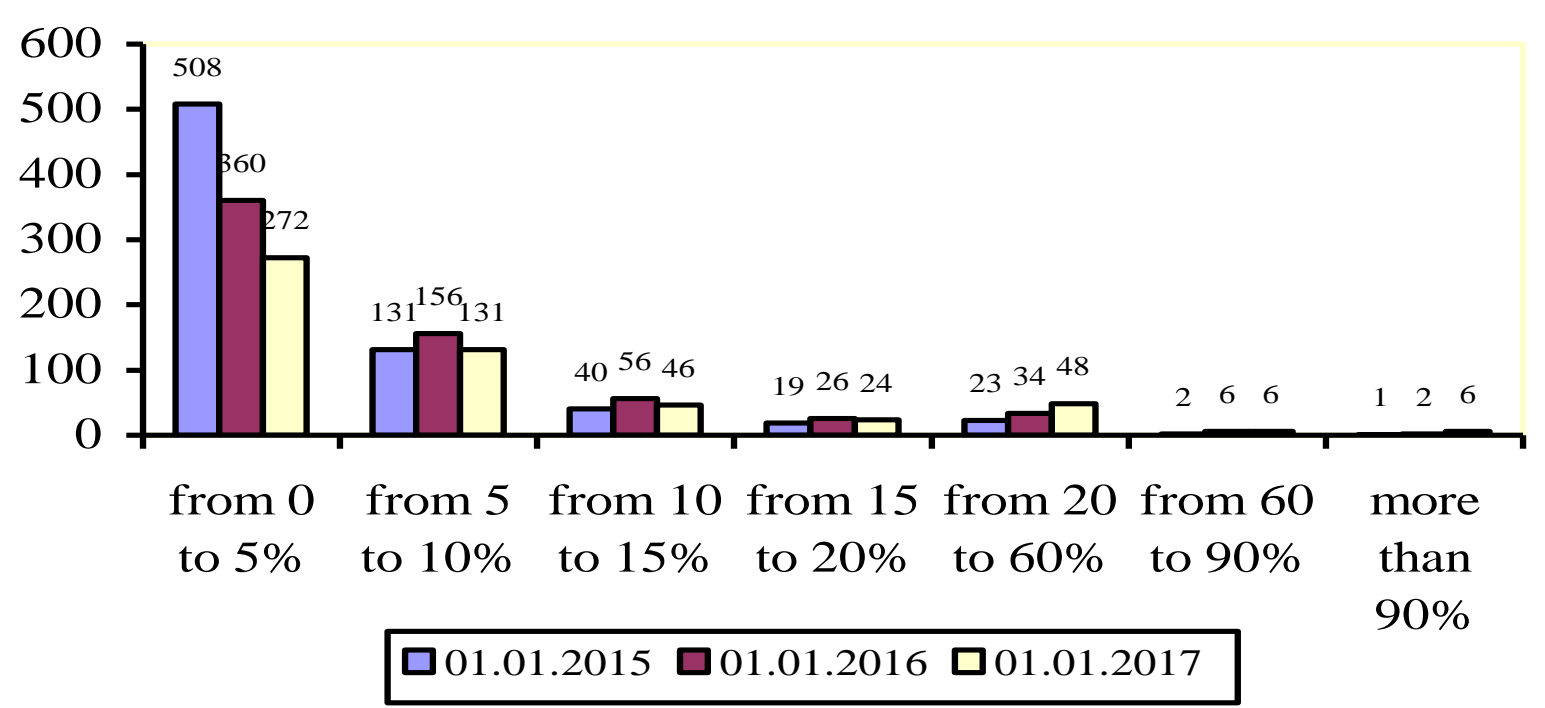

Figure 2. Distribution of credit organizations by the proportion of overdue debt in the loan portfolio of Russian banks.

Source: compiled by authors

The share of overdue loans in loans to non-financial organizations and individuals is observed a similar trend: in 2016, a sharp jump in the share of overdue loans is visible, and by 2017 the growth rate slowed down, and as of 01.01.2017, the proportion of overdue loans in physical loans decreased persons. The increase in the share of overdue loans in loans to individuals in 2017 reached $8.2 \%$ with an increase in loans to individuals by $1.1 \%$, which is higher than the maximum of the last crisis - 7.5\% on 08/01/2010 (Tovpeko, 2018) (figure 3).

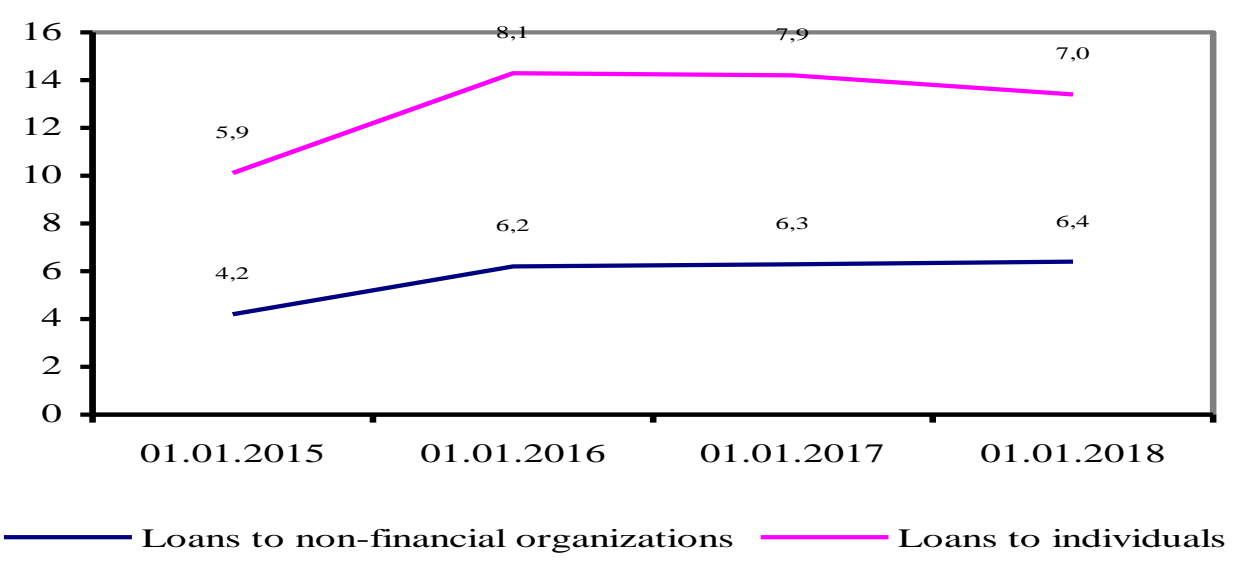

Figure 3. The share of overdue debts in loans and other means to non-financial organizations and individuals in Russia. Source: compiled by authors

A large share in the debt on loans to individuals is accounted for by mortgage loans - $33.1 \%$, housing loans (except mortgage loans) $-9.4 \%$, and car loans $-5.6 \%$. 
The amount of major credit risks in the banking sector in 2016 increased by $17.7 \%$ compared to the previous year, and in 2017 decreased by 10\%. In 2018, there is a slight increase in this indicator by 1\% (21,247.1 billion rubles). The assumption mentioned above about the reduction in the amount of major credit risks since 2016 was confirmed.

You should also pay attention to the quality of the loan portfolio. As of 01.01.2018, the share of loans of the I and II quality categories was $82.5 \%$, the share of loans of the IV and V quality categories (bad loans) over the 2 years increased from 6.8 to $9.5 \%$. In general, in 2015-2018 there is a noticeable tendency towards a decrease in the share of standard and non-standard loans and an increase in the share of doubtful, problematic and bad loans (table 10) (Tovpeko, 2018).

Table 10. Dynamics of the structure of loan debt of the banking sector of Russia

\begin{tabular}{|l|c|c|c|c|}
\hline \multirow{2}{*}{ Loan Quality Category } & \multicolumn{4}{|c|}{ The share of loans classified by quality category, \% } \\
\cline { 2 - 5 } & 2014 & 2015 & 2016 & 2017 \\
\hline Standard & 46,8 & 45,2 & 44,0 & 44,9 \\
\hline Non-standard & 39,5 & 38,3 & 38,1 & 37,6 \\
\hline Doubtful & 6,8 & 8,2 & 8,5 & 7,5 \\
\hline Problematic & 2,2 & 2,4 & 3,0 & 3,1 \\
\hline Hopeless & 4,6 & 5,9 & 6,5 & 6,9 \\
\hline
\end{tabular}

Source: compiled by authors

A positive factor for the period under review is the maintenance at a fairly high level by banks of the volume of reserves formed for possible losses on loans. As of 01.01.2018, the accumulated reserves for possible losses on loans amounted to $9.3 \%$ of the total loan debt in 2016 and 2017 this indicator was at the level of 7.8 and $8.5 \%$, respectively.

Thus, currently there is a tendency to increase the share of overdue debt in the banking sector of the Russian Federation. The increase in the share of delinquency in loans granted to individuals is recorded to the greatest extent. By 2018, there has been an increase in the share of large banking risks and the share of loans of IV and V quality categories. All of this generally indicates an increase in credit risk in the banking sector, which in the long run may lead to the inability of the bank to meet its obligations and its further liquidation.

\section{Conclusions}

The banking sector in the modern world is one of the leading components of the financial system. For this reason, its stability and efficiency is one of the key conditions for the full and "healthy" development of the country's economy.

A large share in the banking sector is occupied directly by commercial banks, the main goal of which is to make a profit. Each bank independently chooses the most suitable set of tools to achieve its goals. At this stage, a peculiar conflict of priorities arises: for banking, the key is high profitability and the search for ways to achieve it, and for counterparties, the stability and reliability of the bank as a partner. Often, in the pursuit of high profits, banks pursue a rather risky policy, losing their liquidity and solvency, and as a result, their financial stability is reduced. 


\section{ENTREPRENEURSHIP AND SUSTAINABILITY ISSUES}

ISSN 2345-0282 (online) http://jssidoi.org/jesi/

2020 Volume 7 Number 4 (June)

http://doi.org/10.9770/jesi.2020.7.4(47)

Thus, summing up, we would like to note that the amount of overdue debt remains an urgent problem for all countries that have been considered in the article over the past few years. Both banks and government agencies are trying to solve it, and certain successes have already been achieved, but stability is still a long way off. More than once, optimistic numbers were followed by another deterioration of the situation, and then it again straightened. The results for 2018 again inspire optimism. Undoubtedly, an improvement in the quality of assessment of borrowers thanks to modern scoring systems has also contributed to changes in the field of lending.

And this is precisely what the state's intervention is affecting, which has repeatedly legislatively limited banks in issuing high-risk loans in order to correct the catastrophic situation that the sector came to several years ago.

Banks are forced to take a more careful approach to assessing borrowers and analyzing risks so as not to be subject to sanctions. And the point is not that the requirements have become more stringent, but that banks more carefully draw up a portrait of the borrower and analyze it before deciding whether to grant or not to issue a loan.

Roughly speaking, the requirements as such do not fundamentally change, simply if earlier, with a superficial analysis of a potential borrower, which was often carried out manually, the picture was favorable for a loan, now that the portrait is drawn in more detail, there are more opportunities to see the pitfalls. This largely explains the fact that the volume of loans issued by STBs in these countries decreased over the year.

\section{References}

Aleksandrov, A. Yu. 2017. Abstract of the dissertation on the topic "Management of a portfolio of problem loans of a commercial bank". http://economy-lib.com/upravlenie-portfelem-problemnyh-kreditov-kommercheskogo-banka\#ixzz3p8wy7quv

Aliev, O.M., Ibragimova, D.M., Dzhamalova, P.I. 2016. Features of the management of problem loans in the activities of a commercial bank. Economics and Entrepreneurship, 11(27), 35-39.

Ashraf, M., Masood, O., Tvaronavičienè, M., Aktan, B., Garškaitè-Milvydienė, K. Lace, N. 2019. Factors Affecting Development Patterns: Econometric Investigation Of Japan Equity Market, Economic Research-Ekonomska Istraživanja, 32(1), 440-453, https://doi.org/10.1080/1331677X.2018.1551147

Association of Banks of the Republic of Kazakhstan. 2018. The Problem of Bad and Bad Credit - NPL. Banks of Kazakhstan, 5 (251), 4556.

Baibulekova, L. 2016. Management of bad loans: the Kazakhstani experience. Actual problems of the economy, 8(146), 183-189.

Bizin, S. S. 2016. Methods of managing problem loans in a commercial bank. Young scientist, 20, 272-275.

Caplinska, A., Tvaronavičienė, M. 2020. Towards sustainability of financial system via complex assessment of borrower's creditworthiness Journal of Security and Sustainability Issues, 9(4). http://doi.org/10.9770/jssi.2020.9.4(23)

Data of the National Bank of the Republic of Kazakhstan. 2018. www.nationalbank.kz

Electronic resource: $\underline{w w w . i n f o b a n k . b y}$

Fakhry, B., Aktan, B., Masood, O., Tvaronavičienė, M., Celik, S. 2018. The Impact Of A Recent Natural Disaster On The Japanese Financial Markets: Empirical Evidenece. Journal of Competitiveness, 10(2), 56-71, ISSN 1804-171X (Print), ISSN 1804-1728 (On-line). https://doi.org/10.7441/joc.2018.02.04

Platonova, Yu.Yu., Zaichenko, S.E. 2018. Tools for managing a portfolio of problem loans in modern conditions. Finance and Credit, 4 (436), 28-36. 


\section{ENTREPRENEURSHIP AND SUSTAINABILITY ISSUES}

ISSN 2345-0282 (online) http://jssidoi.org/jesi/

2020 Volume 7 Number 4 (June)

http://doi.org/10.9770/jesi.2020.7.4(47)

Potapeyko, D.A. 2014. Methods for improving the work of banks with problem loans. Modern scientific research and innovation, 12. Retrieved from: http://web.snauka.ru/issues/2014/12/41903

Rahman, A., Tvaronavičienè, M., Smrčka, L., Androniceanu, A. 2019. The Effect of Bank Competition on Cost of Credit: Empirical Evidence from the Visegrad Countries. Acta Polytechnica Hungarica, 16(4), 175-195.

Rubleva, E.N. 2017. Management tools for problem loans of banks. Business. Education. Right, 4 (21), $200-202$.

Siddique, A., Masood, O., Javaria, K., Huy, D.T.N. 2020. A comparative study of performance of commercial banks in ASIAN developing and developed countries. Insights into Regional Development, 2(2), 580-591. https://doi.org/10.9770/IRD.2020.2.2(6)

Statistical Bulletin of the National Bank of the Republic of Belarus. 2018 . http://www.nbrb.by/publications/bulletin/Stat_Bulletin/_2018_01.pdf

Tagirbekova, K. R. 2015. Fundamentals of banking. The whole world. Moscow. 269p.

Tovpeko, P.A. 2018. Credit risk analysis of the banking sector of the Russian Federation in 2015-2018. International Student Scientific Bulletin. 2.

Tvaronavičienè, M., Masood, O., Javaria, K. 2018. Preconditions of the Eurozone economic security: how to overcome liquidity risk and cost inefficiency in leading banks of UK and Germany, Polish Journal of Management Studies, 18(1)418-427; https://doi.org/10.17512/pjms.2018.18.1.31

Website data: www.afk.kz

World Development Report Digital Dividends. World Bank Review. 2016. www.worldbank.org

Yusupova, O.A. 2015. About overdue debt in loan portfolios of Russian banks, the reasons for its occurrence and methods of working with it. Finance and Credit, 3(627), 14-26. 
Kalamkas RAKHIMZHANOVA is a PhD student of the Eurasian National University named after L.N. Gumilyova, NurSultan, Kazakhstan. Research interests: loans, problem loans, financial management.

ORCID ID: orcid.org/0000-0001-8004-4326

Serik MAKYSH is a Doctor of Economics, Professor of the Eurasian National University named after L.N. Gumilyova, Nur-Sultan, Kazakhstan. Research loans, problem loans, financial management, financial institutions and services.

ORCID ID: orcid.org/0000-0002-6748-4826

Botagoz SAPAROVA is PhD, professor of the Eurasian National University named after L.N. Gumilyova, Nur-Sultan, Kazakhstan. Research loans, problem loans, financial management, financial institutions and services.

ORCID ID: orcid.org/0000-0002-0881-3474

Iskakov BAURZHAN is a Candidate of Economic Sciences, assistant professor of the Turan-Astana University, Nur-Sultan, Kazakhstan. Research loans, problem loans, financial management, financial institutions and services.

ORCID ID: orcid.org/0000-0002-3989-7631 